Article

\title{
The Career of the Lógos: A Brief Biography
}

\author{
D. H. Williams
}

Department of Religion, Baylor University, Waco, TX 76798-7284, USA; DH_Williams@Baylor.edu

Academic Editor: Marcin J. Schroeder

Received: 16 August 2016; Accepted: 12 October 2016; Published: 29 October 2016

\begin{abstract}
This paper is a review of the influence that lógos has had on ancient Greek, Jewish, and Christian writings. During the philosophical era known as Middle Platonism, the concept/ontology of the lógos played a unique role in enabling Pagan, Jewish, and Christian intellectuals to communicate on a small space of common ground.
\end{abstract}

Keywords: lógos; episteme; Middle Platonism; Sophia; memra; lógos spermatikos; lógos prophorikos

\section{Introduction}

Ancient Greek philosophy bequeathed to subsequent cultures its unique methods of investigating the being of the universe through reason. Two of the most important problems generally addressed are well known. The first has to do with proposing realities of stability and permanence in an ever changing world; the second is the problem of the "One and the Many", that is, how to relate the diversity and plurality of visible things to an orderly and unified cosmos. In their search for such principles, the Greeks argued that the cosmos-from stars to souls-was perfectly arranged, possessed coherence, and could therefore be explained. However, implicit to these problems was the most important question of all: how did the divine, or utterly transcendent, invisible, and immutable interface or intersect with the material, temporal, and mutable world. This was the great philosophical quest - within all the Greek schools and for most religions as well. Related to this, for those schools of thought that posited the necessity of an intersection, there was a problem about how this occurred and how far it occurred. This problem was only further compounded by the supposition that the material and mutable had its origin from the unseen and immutable, as one finds in Platonism and Judaism. The "problem", as I'm calling it—something common to Pagan, Jewish, and, later, Christian believers—-was the ontological tension that the unseen, immutable, or divine (as in the case of Heraclitus) must act in forming the mutable, temporal world, without violating the nature or properties of its divine essence or power. As we will see, this all has bearing on the role of the "lógos" ( $\lambda$ ó $о \sigma)$ in its Greek development, whether this be Pagan, Jewish, or Christian.

The concept of the lógos ( $\lambda$ ó it did not begin this way. Its origins were more chaotic. Debate about the logos was exceedingly common among different schools of philosophy, though most agreed in principle that the concept of lógos was polysemic in that it conveyed several meanings at the same time. During the fourth through fifth centuries B.C., the greatest evolution occurred in the use of lógos in a rational sense, which determined the relation of unseen realities from the mere appearance of things (the seen). Etymologically speaking, the Greek noun lógos is derived from the verb légein, "say"; this linguistic origin was permanently etched into its meaning, as we will see. Greek philosophers certainly made extensive use of it in a wide range of meanings-word, assertion, definition, interpretation, explanation, reason, criterion, proportion, relation, argument, and rational discourse-but also used logos with the general and indeterminate meaning of "report", "presentation", and "narrative of or about something."

The multivalent interpretation of lógos is perhaps best demonstrated by attempts to translate it into another language. In Latin texts, lógos is translated as sermo or verbum [1], both of which had 
more to do with a mode of speech (i.e., proverb, discourse) or with the manner of speaking (such as conversation), but it might occasionally be transliterated "lógos" in order to preserve the breadth of its meaning. In English, lógos is most often translated as "word", adhering to the Latin limitation, though it is just as accurate to use the nouns: reason, mind, intellect, and other synonyms.

Among its many transformations and applications, the lógos supremely became the ultimate communicative act of God toward animate and inanimate creation. Given the centrality of the essence of lógos within varied philosophical systems (which include Judaism and Christianity), I wish to show more precisely its importance as a comprehensive designation in the ancient Mediterranean world. Most everyone imparted to the lógos a necessary operation of the Divine in the world that made possible knowledge and ethics. Strangely, scholarly work on understanding the lógos through the ages is lacking attention, though much has been written about lógos in ipsum. Most who write about the lógos do so on the way to some larger topic. In a short paper, I cannot do justice to the subject, so I wish to offer several examples of how the concept was first utilized in several contexts and draw some implications.

One must confront the fact that there has been no uniform understanding about the logos in the sense that there has been no unifying doctrine. Even within the same philosophical "school", there may be several definitions. Nevertheless, there is a platform of common features that the varied fragments and statements demonstrated about the identity of lógos. By the early Hellenistic period, it was used to express the rationality in man as well as the divine. In the course of its evolution, the lógos also functions as the divine law or will of God as expressed in the natural universe or by special revelation. However it was applied, the lógos was first and foremost a philosophical utterance that offered metaphysical transcendence as much as immanence. In other words, the lógos could serve as an ontological bridge connecting the seen and unseen realms.

\section{Pre-Socratics}

Attempts to trace the use of the word in detail have proved to be unsuccessful. It is, however, evident that lógos was already being used by the Pre-Socratics, chiefly in Heraclitus of Ephesus (sixth century B.C.). We find the term lógos for the first time in the fragments of Heraclitus, not only as a designation for his own understanding and interpretation of things, but also as the only unifying formula for the arrangement of things in the world. Heraclitus of Ephesus, who lived in the sixth century, B.C., was the first philosopher we know of to give lógos a philosophical or theological interpretation. Heraclitus might in fact be called the first Western philosopher, since his writings were perhaps the first to set forth a coherent system of thought akin to what we now term philosophy. Although his writings are preserved in approximately 130 fragments, we know that he described an elaborate system touching on the ubiquity of change, the dynamic interplay of opposites, and a profound unity of things [2]. The lógos seemed to figure heavily in his thought, making him the first philosopher we know of to give lógos a philosophical or theological interpretation. He described it as a universal, underlying principle through which all things come to pass and in which all things share.

Fragments 1 and 2 remain critical to formulating a basis for understanding [3].

1. "Although this lógos always exists, men are ignorant [of it] both before they hear and after they have once heard. For even though all things happen in accordance with this lógos, they are like men of no experience when they experience words and deeds such as these..."

2. "... it is necessary to follow the common. However, although the lógos is common, the many live as if they had a private understanding."

Lógos as a cause and universal (common) also has a regulating function in that everything is governed and ordered by it. Human ignorance is not an obstacle to the efficacy of the lógos. Its activity may catch certain people by surprise since they live according to their limited dictates of conscience 
or knowledge. Nonetheless, the lógos should be regarded as "common" or, presumably, a universal endemic to reality.

Here, lógos was an immanent principle that was omnipresent in things. Heraclitus' lógos also appeared to have a material embodiment, as if it were a physical force, related in a sense to the primordial element fire. The human lógos was in a position to comprehend that lógos, since human reason (lógos) in particular, existed as part of the universal lógos; as per Fragment 115: "The soul has a logos which increases itself [within the soul]. A very similar conception is shared by Isocrates (from the fourth to the fifth century B.C.), which is that the logos has a regulating function in that everything is governed and ordered by it. Stoicism will find this line of thought central to its own purposes.

\subsection{Plato}

It has been noted in the past that Plato omits a surprising amount of pre-Socratic thought [4]. Moreover, it seems likely that Plato and Aristotle were simply ignorant of many important pre-Socratic ideas. However, this picture does not tally with the logos appearing as the faculty of reason both in Plato (Laws 689D; Tim. 89D) and Aristotle (Eth. Nic. 102b 26); Aristotle employs lógos to mean the definition or essence of a thing (Meta. 993a 17) and the principles that exists in law (Pol. 1286a 17), whereas Plato speaks of lógos as that which is added to true opinion to make it knowledge (Theat. 201C). Plato's use of lógos in the Theaetetus has been a matter of ongoing debate. The question at the center of this dialogue is about the problem of knowledge, "How do I know that my judgement (my opinion) is true?" That is, what is the criterion for distinguishing true from false judgement? A lógos is an account (or explanation) that records a distinguishing mark or nature of an object $[5,6]$. The Theaetetus seems to end on a negative note as if to say we will fail to come to an understanding of the nature of knowledge based only on our sensations and our opinions. Yet Theaetetus reports a definition of epistêmê as "true belief with logos" (Theaet 201c-d.), and Socrates seems to agree.

Clearly, lógos is an essential ingredient for possessing a true knowledge of anything. However, there is also in Plato the lógos that makes virtue possible.

one sees and contemplates things that are set in a regular arrangement and are always in the same condition - things that neither do injustice to one another nor suffer it at one another's hands, but remain all in order according to reason (lógos)... (Rep. 500c).

The lógos makes possible the harmonious arrangement of the eternal and unchanging order which is the foundation for our imitation and growth in virtue.

While there seems to be two applications of the lógos, it has been argued that Plato presents broadly similar interpretations of lógos, namely, that which transforms Platonic quasi-virtue into full virtue, and that which transforms lesser states of knowing (one's experience or opinion) into a certain epistêmê, or other forms of wisdom [7]. Exactly how one goes about achieving an appropriation of the lógos seems to be another aspect of the allusiveness often encountered in the Platonic dialogues.

\subsection{Stoics}

Lógos doctrine is a capital element in the system of the Stoics and may be said to have contributed the most to the lógos' application toward arriving at meaning and morality [8]. Very much has been written on this subject that I cannot treat here (The major discussions are found in [9-12]). Broadly stated, the Stoic perspective regards physics and theology as correlatives. The material universe pulsates with living being, the lógos or rational principle that resides in everything, including the human soul. This intrinsic reality is in fact God or the governing principle of all things, meaning that everything operates according to providential ordering imbued with the lógos.

For the Stoics, the lógos within everything can be accurately described as pantheism, about which the North African writer Tertullian remarks how Zeno of Citium (the reputed founder of Stoicism) taught that the lógos pervaded throughout the material world as honey runs through the honeycomb (Tertullian, Ad nat. II. 4). The point here is that the lógos functions as an active principle imbuing and 
determining the course of the cosmos. Unlike early Platonic thought, Zeno is said to have considered "the lógos is the creator and adjuster of everything in nature." As a spiritual power, "the lógos authored the world and pervaded every part of it." (Tertullian, Apol. 21). For this reason, the lógos was known in Greek as the "lógos spermatikos" (seeding of rationality). At the same time, Stoicism also embraced a kind of panentheism (Cicero, De Nat. Deo. I. 40-41; Athenagoras, Plea, 6.4; 22.5); that is, the divine does not merely produce all, but the divine soul is within all. Because the Divine Reason inhabited everything, a moral order existed in the creation as well as within the human soul. It is no wonder that the Stoics defined philosophy as "striving after wisdom."

As far as Hierocles the Stoic was concerned, the gods are immutable and fixed in their judgments, never wavering from what they originally decreed [13]. However, it was no less true, Hierocles acknowledged, that "epic poetry", that is, the creative expression of realities, gives credence to how pliable and mutable the gods are in their actions toward human affairs, since they are manifestations of a unitary divine power. Early twentieth-century scholars [14] criticized Stoicism for misconstruing the earlier understanding of lógos, but this seems unnecessary. Even if we grant that the Stoic lógos was a more metaphysically extended concept than Heraclitus would have entertained, it does not follow that the Stoics totally misrepresented Heraclitus in this regard. It is not possible to pass off so simply that the cosmic-metaphysical interpretation of Heraclitus' lógos was a completely Stoic invention (Miller, 165).

Some explanation was necessary if the world (kósmos) were orderly and the lógos were the general plan according to which everything happened-or the model for the harmony and balance between the diverse opposing forces in the universe. The unity of the Heraclitean fragments-the comprehension, continuity, and progression of ideas-is such that the logos idea, if not the word itself, pervades the whole.

\subsection{Philo Ioudaios (Judaeus)}

We now turn to Philo, a Jewish literati who lived in Alexandria during the same years that Christ lived. A prolific writer with some forty-eight separate treatises to his credit, Philo was ironically used widely by Christians though not by Jews. With the exception of Josephus (another Hellenist Jew from the first century), neither Talmud nor the Midrash ever mention him [15].

Most of what we know about Hellenistic Judaism is drawn from Philo (some from Josephus), his writings supplying valuable data for the philosophical eclecticism of Platonist, Stoic, and Pythagorean elements known as Middle Platonism, which was considerably influential upon the later Christian Platonists in Alexandria. It is not difficult to find on nearly every page of Philo's writings an intimate knowledge of Greek literature; Homer, poets such as Euripides and Demosthenes, and especially Plato (his favorites being the Timaeus and the Phaedrus). It was said of Philo that not only did he talk like a Greek, but he also had the soul of a Greek. As noted earlier, Philo read and studied the Bible, not in Hebrew but in Greek. There was nothing contradictory in his mind between Scripture and philosophy, the latter being the means by which one obtained wisdom. "For philosophy is the practice and study of wisdom, and wisdom is the knowledge of things divine and human and their causes" (On Consorting with the Preliminary Studies XIV. 79).

The Pentateuch, the first five books of the Hebrew Bible, was the unquestioned authority in all matters of belief and practice: indeed, a great many of Philo's treatises are commentaries on the Bible. Greek culture and philosophy is the unmentioned but omnipresent backdrop by which the principles about God and ethics could be understood or be realized. In particular, Philo selected the Platonic paradigm of being and becoming, immutability and change, and knowledge and ignorance as the system of thought most suitable for the task of expounding and interpreting the truth revealed to Moses. Plato is often admired by Philo as the Pagan thinker closest to the truth of biblical revelation [16]. At the same time, the greater revelation for Philo was how the apparently primitive Jewish collection of texts-Genesis, Exodus, Leviticus, Numbers, and Deuteronomy-when read with a properly 
trained eye through allegorical and metaphorical reasoning, contained the highest and most profound philosophy [17].

Even greater than Plato, Moses was himself the greatest of philosophers, whose teaching laid the groundwork for Greek thinking on all matters of ethics and metaphysics. However suspect modern historians may find his historical framework, Philo was drawing on an already common argument in antiquity. Another Egyptian Jew named Aristobulus asserted two centuries earlier that the ideas of the best Greek poets and philosophers were anticipated by Moses in the Torah (Cited in Eusebius of Caesarea, Prep. Evang. IX. 27). These same themes resurface in Josephus, who re-asserted the antiquity of Jewish legislation and custom (Which he had already done in his twenty books entitled, Antiquity of the Jews.), declaring that Moses was the father of Greek philosophy (Contra Apion II. 168). In the Jewish mind, Mosaic chronological priority helped to explain why there existed so many ostensible parallels between Greek and Hebrew scriptural ideas [18].

It was likewise Philo who widely integrated the multivariate notion of the lógos, using it more than 1300 times in references to the lógos as the Divine Reason, by participation in which humans are rational; the model of the universe; the superintendent or governor of the universe; and the first-born son of God. Characteristic of Middle Platonism, Philo joined Platonic and Stoic streams of identifying the Divine lógos as the Supreme Principle, distinguishing the lógos as a second subordinate divine principle, and combined them to form an intelligible pattern that strongly impinged on Christian thought. On the one hand, the Supreme Deity is the God of the Old Testament, the God of Abraham, Isaac, and Jacob. This God is the same as the Platonist Highest Good or Supreme God, whose being possesses many of the philosophical hallmarks as utter transcendence and the Absolutely One and Simple (Philo, Allegorical Laws II. 21, 86; On the Migration of Abraham 125; Alleg. I. 51; II.2, 3).

On the other hand, the wholly transcendent God was made known to humanity in time and creation through the agency of the lógos, whom Philo describes variously as a Divine mediator between God and the world. The lógos, in this latter instance, exists as a subordinate, intermediate being, although it is not always clear what Philo has in mind, nor does he ever render for the reader a concrete definition (At other times in his writings, the lógos seems to be a representative force or special presence of God.).

Philo shares with his philosophical era the portrayal of the Divine lógos usually as a personification of the Platonic Ideas, in a manner similar to the way a builder is said to have implanted in his mind a plan for constructing a city (On Fashioning the World 4.17). Thus, too, the lógos functioned as God's noetic tool for creating the world. Along lines similar to Platonism, the lógos functions as the demiurge of the Timaeus, completely subordinated to the Supreme God (Republic). It is God who creates the world via the lógos. Without trying to be too confusing, Philo seems to have subjoined the transcendent God of Platonism with the immanent logos of the Stoics, though in his own configuration [19]. This was an essential insight that Christians would later adopt. Knowing of the close nexus of Greek thought and Judaism in the centuries before the time of Jesus, it is not surprising that Christianity assumed a proportionally greater degree of the Greek philosophical tradition through the Philonian matrix.

At the same time, Philo does not avoid the language of the personal God found in the Old Testament. In those places where we find immanent moments of God interacting with creation (Gen 1-3) or human beings (Abraham, Gen 12; Moses, Ex 19-20), we are reminded that this is accomplished through the agency of the logos as the mediator between the utterly transcendent God and the material world.

\subsection{The Lógos of John and Greeks}

The Gospel of John begins with a prologue that is quite unlike the other gospels and is itself a most remarkable statement: "In the beginning was the lógos and the lógos was with God and the lógos was God." Like the surrounding intellectual culture, the term lógos here contains an elasticity of meaning that qualified the unique self-expression of God that always existed, always acted as the Divine reason or intellect, and had been the agent whereby God creates the visible world. Some New 
Testament scholars have argued that the occurrence of this term as a divine name cannot be due to the influence of Greek philosophy [20], but this is disputable. While we will never know the exact original intention of the author of the prologue, philosophers-both Christian and Pagan-came to regard the statement as the epitome of a philosophical ontology. Indeed, Christian intellectuals in the second and third centuries often presented Christianity not merely as a philosophy, but as the sole and eternal philosophy [21]. The conceptuality of the lógos played a central role in making this happen.

Among the countless models invoked as an ideological prototype for John's pre-existent lógos, Werner Kelber has contended that Jewish Wisdom is the best candidate. Coming forth from the mouth of the Most High, Wisdom existed at the beginning before the world was created (Wis 9:1-2; Prov 8:22-23). Subsequent to her participation in the work of divine creation (Prov 8:27-31), she was sent down from the heavenly abode to make a dwelling place on earth (Wis 9:1-2; Sir 24:8ff). Whoever finds her will find life (Prov 8:35), for she is like a tree spreading forth its branches of glory and grace (Sir 24:16). However, she cannot herself find a resting place on earth, because all foolish men reject her (En 42:2). This Wisdom presentation in the canonical and apocryphal books of the Hebrew Bible offers "good parallels for almost every detail of the prologue's description of the Word." It clearly provides us with a key to the principal operations of the lógos [22].

If Kelber is right, then why does the prologue introduce the Son as lógos and not as wisdom? Use of lógos is clearly deliberate and presents a philosophical context by which this gospel begins. In response to Kelber, surely Hellenistic Judaism has just as much a role to play in interpreting the prologue. It was common by the first century to use wisdom and lógos as synonyms. That is, in Hellenic Judaism, there was an interchangeability of sophia with logos as exemplified by Philo's transference of sophia attributes upon the lógos. To this one should also add the role of the meaning of the Hebrew "memra" (dibbur). It is difficult to say how far the rabbinical concept of the memra ("dibbur"), which was used in parallel to the divine Wisdom, had come under the influence of the Greek term logos. However, Philo must have been aware of the memra as a cosmic power that extended from God to affect His will [23].

Considering John's prologue more carefully, the lógos is said to be with God, which suggests a distinction between God and his Word. However, the lógos is also named as God of God, as if it were an aspect (species) of divinity [24]. Pierre Hadot has contended that Christian philosophy was made possible by the ambiguity (or polysemy) of the Greek lógos. As "Word", "rational force", "discourse", or "explanation", the lógos was easily fused with other personifications. John's prologue does not at first fully identify the lógos, but by John 1:14 it is announced that the lógos is the Son of the Father. Such language had already been used by Philo, just as we saw Philo's reference to lógos as "first-born son." However, it should be said that we cannot be certain that Philo is the source-certainly not the sole source-for the prologue author's portrayal of the logos.

An equally likely place to find precedents is the "Wisdom literature" of the Hebrew Scriptures (Ps, Prov, Job, and others). Given the strengths of these precedents, one scholar has argued that we should ignore Philo and look solely at the Scriptural evidence [25]. In several instances, we find the term "word" used (either as lógos or rhēma), usually being linked with God's majesty or action. Ps 106:20 states that the word is sent by God to heal: "He sent His word (logos), and healed them," and Ps 147:15 reads, "God Who sends forth his speech throughout the earth: His word (logos) runs swiftly." We might also look at the Apocryphal OT: "By his word (lógos) all things are regulated" (Ecclus 43: 28). It all sounds much like Jn 1:3 and 9: He is the one through whom God "made all things" and is "the true light that enlightens every man."

Of course we are drawn to Prov 8, where we do find Wisdom (Sophia) in a personified form.

22 The Lord created me at the beginning of his work, the first of his acts of old.

23 Ages ago I was set up, at the first, before the beginning of the earth...

30 then I was beside him, like a master workman; 
and I was daily his delight, rejoicing before him always,

31 rejoicing in his inhabited world and delighting in the sons of men. [26]

For theological and apologetic reasons, a hypostasized "wisdom" (vv. 22-28) will often be found in Christian writers from the second to the fourth centuries as a description of the lógos and of Christ, as the Word or Wisdom of God.

Still, the Scripture-only argument seems both unnecessary and is probably too wary of the influence of non-Christian sources on Christian texts. However, such influences are undeniable. By the mid-second century, Christian thinkers were presenting the lógos in terms that were familiar to Platonists and Stoics. From evidence we have about secular Hellenist opinion, the Prologue was construed as a philosophical text. The Neo-Platonist Amelius, who was no friend to the Christians, calls John "a barbarian," yet affirms the remarks in the prologue:

This then was the lógos, on whose eternal being depended the existence of things that were made, as Heracleitus also would maintain... the Barbarian maintains that He was with God and was God: through whom absolutely all things were made (Eusebius, Prep. Evang. XI. 19).

It seems that Amelius understood a close connection between the Gospel's vocabulary and what is proper to philosophical inquiry (Hadot, 239). This was not an isolated case. Later, we see a marked resemblance in Confessions (Conf. VII. ix,13), where Augustine states quite clearly that he had recently read "some books of the Platonists." It was within these books, though not in the exact words but "with the same sense," that he first encountered the meaning expressed in the prologue of John 1 , which he quotes: "What was made was life in him [the logos], and that life was the light of men. The light shined in the darkness, and the darkness did not comprehend it." The Platonists could not have said it better. As a former materialist and skeptic, Augustine turned from the restless and temporary world to the Divine lógos whom Christians and philosophers identified as God. There is no hint of surprise in Augustine's description that the biblical lógos stood in close proximity to the ontological ordering of the (neo-)Platonists.

It should be noted that rhēma ( $\tilde{p} \tilde{\eta} \mu \alpha)$ and lógos (the two terms are used interchangeably by John) employed in the Fourth Gospel are already used in a theologically and christologically suggestive manner-specifically in Jn 12:48 ("He who rejects me and does not receive my sayings has a judge; the word that I have spoken will be his judge on the last day") and 17:8a,14 ("...the words [rhēmata] which you gave me I have given to them...I have given to them your word"). Both lógos and rhēma abound in the Fourth Gospel, occurring fifty-one times (lógos 39; rhēma[ta], 12). Even Miller admits that the reason why lógos (not rhēma) was chosen in the prologue had to do with its rich character and varied usages that suggest a fuller expression. From whence did this "rich character and varied usages" come?

\subsection{The Christian Philosopher Justin}

In a defense of Christianity written in the mid-second century in order to gain rational credibility among the Romans, Justin shows varied intersecting links between Christian and Greek philosophies. Here again we see effects of Middle Platonism though it should be noted that Justin harnesses philosophical vocabulary for actuating Biblical teaching. His chief interests is in the ways in certain philosophical wisdom is a partial reflection of scriptural principles. At one point, he makes a startling comment: "when we say also that the lógos, who is the first-birth of God, was produced without physical union, and that He, Jesus Christ, our Teacher, was crucified and died, and rose again, and ascended into heaven [...] By this we propound nothing different from what you believe about those whom you esteem sons of Jupiter" (Justin, Apol. 21). Justin is interested in the principle of similarity, which is not to say that he believes Divine generation is found equally between the Christian Gospel and Pagan religion. In fact, Justin is very careful to signal the distinction between classical philosophy and Pagan religion. 
In another text of Justin, he uses the lógos spermatikos principle, but with limitations. He does not hesitate to say that "the seed of God, the lógos is found throughout the world. We have declared above that He is the Word of whom every race of men were partakers" (Apol. 46). This means that all humanity participates in the rationality of the lógos. Justin shows just how Stoicized he is. Plato and Socrates are included since the inner lógos enabled them to come as close to the truth without the benefit of Scriptural revelation. As a result, Justin claims, the teaching of Plato and Pythagoras "have been as a wall and fortress of philosophy to us" (Dial. 5). Elsewhere it is stated: "For whatever lawgivers or philosophers have at any time uttered well or was achieved with hardship according to finding and contemplating the Logos" (II Apol. 10.2). Anyone who led a life directed by reason (lógos) is de facto a Christian, even if he or she knew nothing of Christ. The same governing principle of the lógos is applied to the work of any Pagan philosopher. It is worth quoting Justin here at length.

What each of them proclaimed was good when he saw from a part of the divine spermatic lógos what is connatural to it. But when they contradict themselves in their principal teachings they are shown not to have a secure understanding and infallible knowledge. Therefore whatever things were rightly said by anyone belongs to us Christians because after God, we worship and love the Logos who is from the unbegotten and ineffable God (II Apol. 13.3).

For Justin, all human wisdom as displayed in ethics and pursuing the truth is a result of the lógos implanted in human nature. "We know that the followers of Stoic opinions were decent at any rate with regard to their ethical doctrine, as were also the poets in some respects... for the seed of the lógos had been implanted in the whole human race" (II Apol. 7.1. The phrase "logos spermatikos" only appears in this apology.). On account of the shared lógos, the great philosophers of history offered good guidance, even if this was partial and incomplete. Since the lógos was finally revealed as the Christ of the Christians, the Jews and ultimately the Christians best understood God's purposes as revealed in the lógos.

While a great many Christian thinkers wrote subsequently on the lógos, Justin's constructions remain mostly intact. There was after Justin, however, a shift away from an emphasis on the lógos spermatikos to the lógos prophorikos. This latter is initially articulated by Theophilus of Antioch (Ad Autol. 2. 22). This wholly intrinsic and substantially unified relation within the Godhead might have endured forever had it not been for the act of creation. At this juncture, the lógos "within" (endiathetos) comes forth or, as God's Word, is "spoken" (prophorikos). Here, the translation of logos as "Word" serves as a metaphor of God's utterance. In that act (not "moment") of God's "speaking", the Word comes forth as a distinctive reality: the lógos who is God is also with God and is now reckoned to be God's agent of creation and inspiration. Origen's commentary on Matthew provides a case study.

[T] he disciples say: "We have no more than five loaves and two fish (Mt 14:17). In this way they hint that the five loaves are the perceptible words of the Scriptures, and for this reason equal in number to the five senses. Surely the two fishes suggest the Word made manifest and the Word hidden, as these happen to be a taste of those perceptible things in the Scriptures" (Origen, In Matt 11. 1-2).

For the Christians, however, the lógos prophorikos was not a simple demiurgos. Tertullian is insistent that this reifying act of the lógos does not mean that God created a second god to do his bidding. Any notion of a God begetting a second god seemed too close to the sort of Pagan polytheism that Tertullian radically opposed. Instead, the lógos is said to have been issued from the very substance of the eternal Being and emerged (not divided from) hypostatically for the purpose of revealing God through the creation. Nor is the substance separated-it is only extended in the divine generation of the lógos; He is a spirit of a spirit, God of God (Tertullian, Apol. 21.13).

Somewhere between Justin and Tertullian, Tatian, from Syria, knew and embraced lógos theology as a suitable means of explaining Christian teaching about the Father and Son. Closer to Tertullian's 
account, Tatian lays stress on the way the lógos became known as the utterance of the Father. In this moment of utterance when the lógos is externalized, he is not distinguished from God as if a part of God had been cut off. Using metaphors of speech and fire (Tatian, Orat. 5.2), Tatian holds that the utterance of the Word from the Speaker (God) underscores the distinction between the Speaker and self-existing Word, whereas in the other metaphor it is the same fire that passes from torch constituting no loss or change in the transfer in either flame. More impressive, if lesser known, is the Christian philosopher Athenagoras, who takes us to the very threshold of Origin's "eternal generation" by declaring that God's lógos or Nous is called "firstborn" "not because he came into existence", since he was "eternally rational (logikòs)" within the eternal mind of God. Our familiar passage of Prov 8:22 is quoted in confirmation: "For the Lord, it says, made me the beginning (cf. Jn 1:1) of his ways for his works."

Whereas Athenagoras is not intent, as Justin was, to show the divine revelation of the lógos toward all creation, he wishes to demonstrate that the lógos, as the mind (nous) and reason (lógos) of the Father, does not fall ontologically into the category of created things. In a way that anticipates Origin, Athenagoras makes a sharp division between divine or eternal being and created being. The Son can only be a partaker of eternal being. Philo's legacy begins to slip to the side.

\subsection{Shared Metaphysical and Ethical Ground}

One thinks immediately of divine immutability, a concept that remained permanently etched in Christian theology for defending the inviolability of the divine nature. Others included immortality of the soul, understanding God by way of negation, and the necessity of divine providence in the world. Most of all—and often underestimated—is Christianity's assumption of philosophy as a way of life. In various ways, Greek philosophy served as a model for the rise of Christian philosophy. We have already seen that Christian intellectuals explained Christianity as a philosophy, even as the philosophy. Christians were not prepared to follow the religious elements woven into Greek and Roman philosophical analyses, but it is arguable that Christianity adopted the philosophical cultural structure, which was "a style of life and a mode of being" (Hadot, 240-41). Throughout antiquity, philosophia designated not so much a theory or method of epistemology as it signified a lived wisdom and a way of acting in accordance with reason. Christian philosophy, thus, consisted in living in accordance with the lógos. Since Christianity was certainly connected with a way of life, it was not difficult to present Christianity with a philosophical outlook.

\section{To Conclude}

One cannot fail to notice how much overlap existed between the philosophical theologies of the ancient Mediterranean world, especially between Jewish, Greek, and Christian theologies, whose apprehension of the universe was both rational (or explanatory) and good.

A second characteristic of Greek philosophical systems is their naturalism. This means that the foundations for human behavior are inherent within the design of the cosmos. Stoics, Platonists, and Pythagoreans operate with the task of knowing and responding to the character of the world. The lógos is both the designer and the design within all reality. However, there is also a significant difference on this point. Christianity makes a sharp divide between creator and creation. Augustine maintained what had become the standard Christian understanding by his time: that Greek philosophy brought good guidance to the searching mind, but only imperfectly. There was no question in Augustine's mind how much Platonist metaphysics had shaped his own thinking [27]. Meanwhile, Plato raised the right questions but could never fully answer them. Only the Wisdom of God, the lógos, was capable of healing the heart and the affections. In the Christian way, this lógos was not a mere principle but, as Clement of Alexandria stated it, "the heavenly Word, the true champion, who is being crowned upon the stage of the whole world" (Protreptikos 1 (Loeb 92.7)).

In sum, we should not fail to recognize an obvious feature about the above narrative. The lógos, through its various overlapping stages, came to function as a kind of glue or adhesive that enabled 
comparable systems to intersect. While this was not an inevitable state of affairs, the pliability of the lógos nonetheless made it an ideal philosophical and theological construct that offered solutions to fundamental problems that had to do with connecting transcendence and imminence. Despite the Greek amalgamation of the poetic and the rational, or Judaism and Christianity's "parting of the ways", the lógos nevertheless became and remained an indelible element of diverse religious systems.

Conflicts of Interest: The author declares no conflict of interest.

\section{References and Notes}

1. The flexibility with the use of verbum came the closest to lógos. Lactantius, a Latin writer (late third century) explains how the Greek lógos is much more expressive of the creator of the world than Latin terms. Div. Inst. IV. 9: "But the Greeks speak of Him as the lógos, more befittingly than we do as the word (verbum), or speech: for logos signifies both speech and reason, inasmuch as He is both the voice and the wisdom of God."

2. The "lógos-fragments" make one group distinguished from others.

3. Of course our construction of Heraclitus' views is just that: a construction of fragments that lack context and relation to each other. This leads to a greater danger of misrepresentation that we wish to avoid. Fortunately there are a great deal of testimonia concerning Heraclitus that makes it possible to have enough confidence in the few conclusions we draw from the evidence.

4. It is well known to pre-Socratic scholars that Plato and Aristotle at many points misunderstood and misrepresented their predecessors.

5. Shields, C. The lógos of 'lógos': Theaetetus 206c-210b. Apeiron 1999, 32, 107-124.

6. Cross, R.C. lógos and Forms in Plato. Mind 1954, 63, 433-450. [CrossRef]

7. Moss, J. Right Reason in Plato and Aristotle: On the Meaning of Logos. Phronesis 2014, 59, 181-230, Both Plato and Aristotle, moreover, broadly agree on what is needed to transform proto-virtue into genuine virtue: some intellectual quality. Sometimes they put this point by saying that the proto-virtuous lack phronêsis (Phaed. 69b, EN 1144b17, Pol. 1277b25) or nous (Men. 100a; Phaed. 82b, EN 1144b12). At other points, however, they put the point in an apparently quite different way: one must have or grasp a lógos, or more specifically the correct or right (orthos) logos. [CrossRef]

8. Gericke, J. Dimensions of the logos: From lógos-Philosophy to logos-Theology. Acta Patrist. Byzantina 2000, 11, 93-116, at 95 .

9. Colish, M. The Stoic Tradition from Antiquity to the Early Middle Ages; Brill: Leiden, The Netherlands, 1985.

10. Rist, J.M. Stoic Philosophy; Cambridge: Cambridge, UK, 1969.

11. Long, A. Stoic Studies; University of California Press: Oakland, CA, USA, 2001; (originally published 1996).

12. Inwood, B. (Ed.) The Cambridge Companion to the Stoics; Cambridge University Press: Cambridge, UK, 2006.

13. How Should One Behave toward the Gods? 1.3, 53. In On Appropriate Acts. Hierocles the Stoic: 'Elements of Ethics', Fragments and Excerpts; Ramelli, I.; Konstan, D. (Eds.) SBL: Atlanta, GA, USA, 2009; p. 65.

14. Notably is Glasson, T.F. A British scholar, Glasson argued that the only lógos in Heraclitus was Heraclitus' own discourse; that is, that there was no cosmic metaphysical principle called the lógos. Glasson, T.F. Heraclitus' Alleged lógos Doctrine. J. Theol. Stud. 1952, 3, 231-238. [CrossRef]

15. "It is plain therefore that pre-Christian Judaism cannot be judged as a whole. After the Dispersion had begun, the Jewish people ceased to be a homogeneous body: its fortunes varied with its geographical distribution, and with its fortunes its attitude towards Hellenism." Gregg, J.A.F. Judaism and Hellenism in the Second Century before Christ. Ir. Church Q. 1908, 4, 291-308, Judaism in Egypt shows the greatest influence of the Greek spirit, but there is no question that Palestine became thoroughly Hellenized (with the exception of Judaea proper) until the time of the Maccabean revolt. [CrossRef]

16. Runia, D.T. How to Read Philo. In Exegesis and Philosophy: Studies on Philo of Alexandria; Variorum: Aldershot, UK, 1990; p. 186, Philo's use of Greek philosophical literature and, in particular, his exploitation of Plato's famous cosmological dialogue, the Timaeus, is extensive.

17. Dillon, J. The Middle Platonists 80 BC to AD 220; Cornell University Press: Ithaca, NY, USA, 1977; p. 141. 
18. Philo, however, was not only influential among Christian authors, since it is highly probable that it is also under his influence that a second-century pagan philosopher, Numenius says: "What More is Plato than a Moses Writing Good Greek?" Van Der Horst, P.W. Plato's Fear as a Topic in Early Christian Apologetics. J. Early Christ. Stud. 1998, 6, 1-14. [CrossRef]

19. The rationality of the lógos is detected in the universe, but being Jewish, he could not subscribe to Stoic pantheism. Both Jews and Christians will draw hard and fast lines between the creator and creation.

20. Ed. Miller wants to claim there is no need to look beyond the gospel of John itself. Miller, E.L. The Johannine Origins of the Johannine Logos. J. Biblic. Lit. 1993, 112, 445-457. [CrossRef]

21. Hadot, P. What is Ancient Philosophy? Harvard University Press: Cambridge, MA, USA, 2002; orig. ed., 1995; p. 237.

22. Kelber, W.H. The Birth of a Beginning: John 1:1-18. Semeia 1990, 52, 121-144.

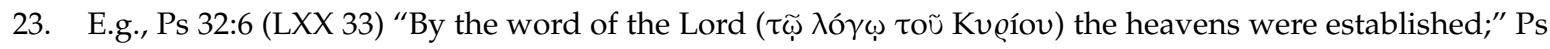

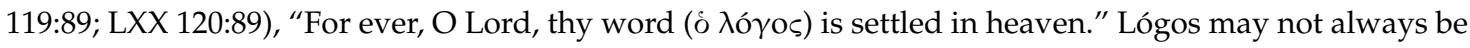
the equivalent in the LXX. Gen 15:1: "the word ( $\tilde{\eta} \mu \alpha)$ of the Lord came to Abram"; Is 55:11, "so shall my word ( $\varrho \tilde{\eta} \mu \alpha)$ be, whatever shall proceed out of my mouth, it shall by no means turn back." The two Greek words have different etymologies but together they combine the conceptualizing of an inner idea/though (lógos) and the rhēma as God's utterance or communication.

24. Tertullian, Adv. Prax. 2 explicitly mentions that the members of the Trinity are the same substance "in aspect." [T]res autem non statu, sed gradu, nec substantia sed forma, nec potestate sed specie, unius autem substantiae et unius status et unius potestatis, quia unus deus ex quo et gradus isti et formae et species in nomine...

25. May, E. The Logos in the Old Testament. Cathol. Biblic. Q. 1946, 8, 438-447, This view assumes Philo would have been largely unaware of or uninterested in the Scriptural evidence which seems unlikely.

26. Also in Ecclus 24, Wisdom is introduced as celebrating her heavenly origin and rule over the created order. Cf. Ecclus 1:1-2: "I came, out of the mouth of the most High..." From this first of the two verses we gather that Wisdom's origin is from God, but as an expression of revelation of God, and Wisdom 9:1: "God of my fathers, and Lord of mercy, who has made all things with your word (logos)."

27. De vera rel. iii.3: You have persuaded me that truth is not seen with the bodily eyes but by the pure mind ...[That] mind has to be healed so that it may view the immutable form of things which remains ever the same, preserving its beauty unchanged and unchangeable, knowing no spatial distance or temporal variation, abiding absolutely one and the same.

(C) 2016 by the author; licensee MDPI, Basel, Switzerland. This article is an open access article distributed under the terms and conditions of the Creative Commons Attribution (CC-BY) license (http:/ / creativecommons.org/licenses/by/4.0/). 